\title{
An Evaluation Performance of Potential Pollution of Arsenic, Chromium and Cadmium in the Road Side Soil of Kirkuk City, Northern Iraq
}

\author{
Hassan A. A. Al-Jumaily \\ Department of Applied Geology, College of Science, University of Kirkuk, Kirkuk, Iraq \\ Email: hassanalauk@yahoo.com
}

How to cite this paper: Al-Jumaily, H.A.A. (2016) An Evaluation Performance of Potential Pollution of Arsenic, Chromium and Cadmium in the Road Side Soil of Kirkuk City, Northern Iraq. Journal of Geoscience and Environment Protection, 4, 80-94. http://dx.doi.org/10.4236/gep.2016.49007

Received: August 21, 2016

Accepted: September 18, 2016

Published: September 21, 2016

Copyright $\odot 2016$ by author and Scientific Research Publishing Inc. This work is licensed under the Creative Commons Attribution International License (CC BY 4.0).

http://creativecommons.org/licenses/by/4.0/

\section{Abstract}

The present work is to evaluate and investigate the distribution of heavy metals (As, $\mathrm{Cr}$ and $\mathrm{Cd}$ ) and to assess the road side samples contamination using an Index (SEPI), (CPI), (GAI), (CF) and (PLI). From right and left Khasa in Kirkuk city, road soil samples were collected in order to estimate the probable contamination level of heavy metals (Cd), (As) and (Cr) in the study area. The heavy metal concentrations were determined in the way side samples by using (ICP-MS) technique. The 22 samples have collected in August, 2013. The results of average levels of heavy metals revealed $\mathrm{Cr}$, As and Cd recorded the highest concentration of (178.6 ppm, $10.4 \mathrm{ppm}$ and 0.599 ppm) in right Khasa respectively. These heavy metals are recorded the lowest value (165.8, 8.29 and $0.4 \mathrm{ppm}$ ) in left Khasa respectively. However, the concentration of $\mathrm{Cr}$ and As was higher than the studied worldwide permissible of contaminated soil. The highest (SEPI) for As in right Khasa and $\mathrm{Cr}$ in left in Khasa seems therefore to be that this road side soil is the most polluted in the city of Kirkuk classified moderately contamination. The accounted of (CPI) for As, $\mathrm{Cd}$ and $\mathrm{Cr}$ ranged from 0.82 to 1.30 with average 1.01 and 0.6 to 1.12 with an average 0.78 in right and left Khasa respectively. The highest values in the right Khasa which suggest multi-elements contamination and suggested this area of study area received more heavy metals comes from manmade and industrial activities. The GAI showed a moderate contaminated with $\mathrm{Cd}$ in right Khasa of study area, while the other metals are in their uncontaminated level. The CF results has been showed by a considerable contamination metals (As, $\mathrm{Cr}$ and $\mathrm{Cd}$ ) in of right Khasa, but low to moderate contamination in left Khasa. The results of (PLI) revealed a deterioration of site quality in all samples of Kirkuk city. Thus the evaluation methods revealed that the studied areas especially right Khasa impacted with heavy industrial activity, phosphate fertilizer, emission of gasses from automobile manufacture tire abrasion and workshop causing an increasing in metal concentrations towards the right Khasa. 


\section{Keywords}

Pollution, Geo Accumulation Index, Contamination Factor, Pollution Load Index, Iraq

\section{Introduction}

Environmental contamination and exposure to heavy metals is a real growing problem throughout the world. The both natural sources and anthropogenic processes spread heavy metals in to various environmental media. The most important environmental issue which caused by anthropogenic activities such as urban road Construction, agriculture waste, sewage disposal and automobile workshop is the emission of heavy metals [1]. The presence of heavy metals has been considered as useful indication for contamination in soil of surface, sediment and dust environments [2]. Atmospheric pollution is the fundamentally sources of heavy metal availability in the environment. These sources include vehicular emissions, industrial discharges and other activities [3]. Emissions from road traffic have contributed greatly to the level of particulate maters both in developed and developing countries [4]. Urban soil is an important ingredient of the urban ecosystem [5]. This can be considered both as a sink of pollutant and source of pollution with the capacity to ground water, into food chain and into the human body [6] [7].

In urban city centers, it is common to see high number of industries and vehicles. Thus making urban centers, a major refuge of resource consumption and chemical emissions may create serious environmental problems if not controlled [8]. Street or urban road side consist of vehicular exhaust particles, household dust, soil dust, construction dust aerosols that are carried clearly by air and water [9] [10]. Heavy metal may come from abundant different sources to the civilian area such is vehicle emission.

Three main factors known to influence the levels of heavy metal inroad side's samples which have been reported are traffic, industry and particularly house and road dust [11]. The soil road dust in urban area is indicators of heavy metals pollution from atmospheric precipitation. These metals can accumulate in top soil from atmospheric precipitation by sedimentation, impacting and interception. The assemblage of these metals to stay in urban soils for a long period of time may pose serious environmental and health problems in the urban city centers [7]. Exposed to weighty metals in road side can occur by means of inspiration, absorption and skinny contact. The pernicious effects of heavy metals in road soil include nervous system retardation, respiratory system disorders, and the risk of cancer in the later life [12]. For this study Kirkuk city was the chosen area. This city is a rapidly developing area, and is considered a major work place in the north of Iraq. It contains many work place parts such as, north oil company, north gas company, cement factory, construction materials and a lot of the fuel stations.

The aim of this study is to evaluate the distribution of heavy metals (As, $\mathrm{Cr}$ and $\mathrm{Cd}$ ) 
and to assess the road side samples contamination using indices Single Element Pollution Index (SEPI), Combined Pollution Index (CPI), Geo-Accumulation (GAI), Contamination Factor (CF) and Pollution Load Index (PLI).

\section{Material and Methods}

\subsection{The Area of Study}

The study area, Kirkuk city the geographical position being $\left(44^{\circ} 43^{\prime} 00^{\prime \prime} \mathrm{N}-44^{\circ} 32^{\prime} 00^{\prime \prime} \mathrm{N}\right)$ and $\left(35^{\circ} 50^{\prime} 00^{\prime \prime} \mathrm{E}-35^{\circ} 38^{\prime} 00^{\prime \prime} \mathrm{E}\right)$ is located in Northern Iraq (Figure 1 ). The altitude above sea level is $(367 \mathrm{~m})$, the area of Kirkuk government around $\left(9676 \mathrm{Km}^{2}\right)$ and represent the ratio about $2.2 \%$ of Iraq.

It is situated on the quaternary deposits formed mainly form river sediments. The study area is arid to semi-arid climate. Naturally, it receipts a significant particulate matter from the atmosphere, and it typically influences by gas emitted from industrial state and automobile exhausts. Kirkuk city is one of the rich-oil provinces with a more

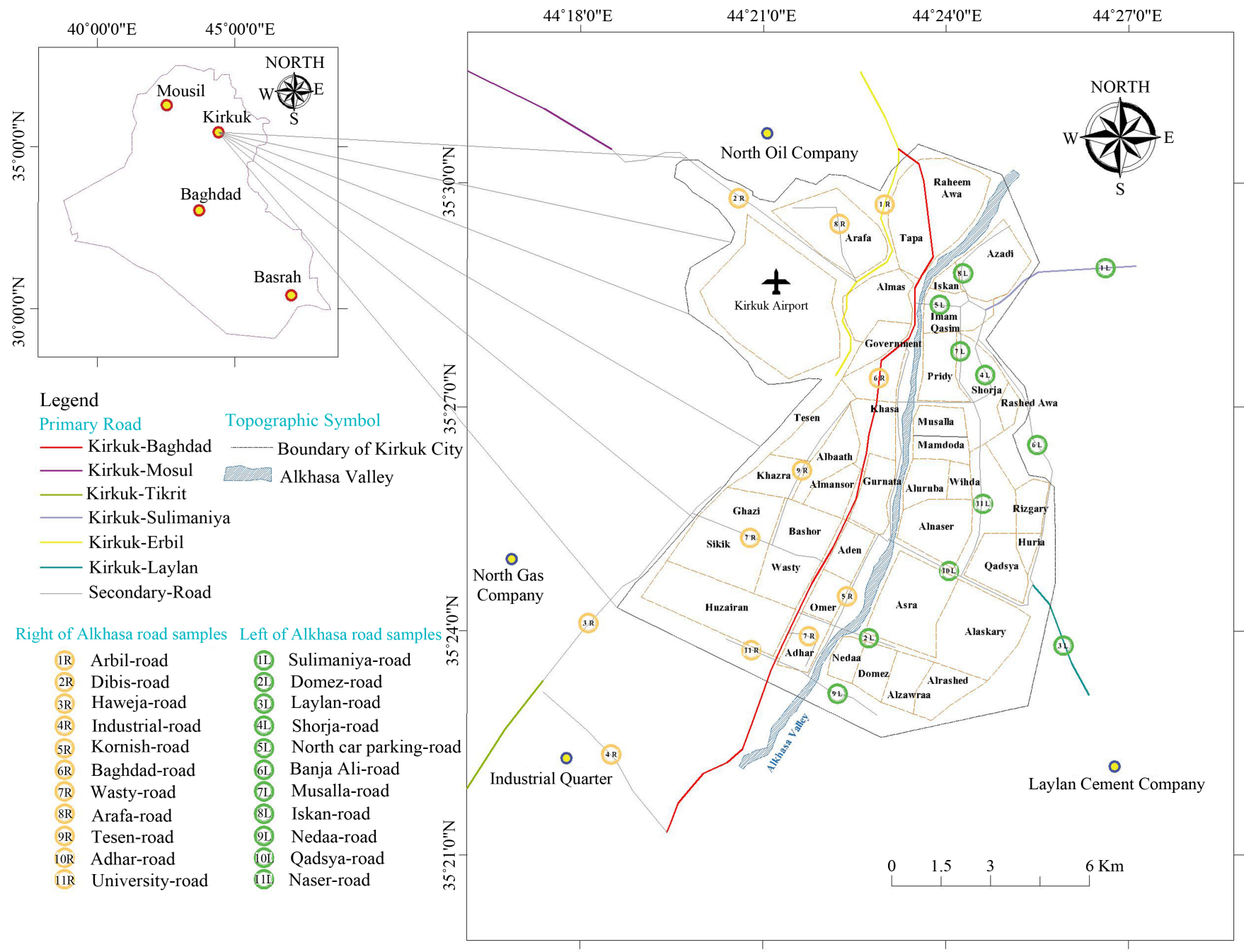

Figure 1. Map of Iraq showing the sample location in Kirkuk city. 
productive soil. The river was divided Kirkuk city in to tow parts right and left called Khasa. Most of industrial state such as (North oil company, North gas company, industrial quarter, Fuel stations mechanical workshop and heavy traffic etc. were located at right part, while in the left part of studied area only cement factory was found in this part with a little industrial state.

\subsection{Sample Collection}

Road side sample of 22 samples (11 samples for each location) were collected from the site using polyethylene cylindrical containers in $8^{\text {th }} 2013$. From within two meter of road side edge these sample ware collected. Using polyethylene brush, dish and containers and were collected in polyethylene containers. The road side soil samples were taken from $(0-20 \mathrm{~cm})$ depth. The samples were dried at $105^{\circ} \mathrm{C}$ to constant mass, and sieved through a $<2 \mathrm{~mm}$ stainless-steel sieve.

\subsection{Chemical Determinations.}

Chemical analyses for the samples of road side soil were performed at the accredited Acme Analytical laboratory of Canada. More specifically, a $0.5 \mathrm{~g}$ aliquot of each road side soil was digested with nitric acid $\left(\mathrm{HNO}_{3}\right)$ and hydrochloric acid $(\mathrm{HCl})$ in a ratio 3:1 at 95C. By coupled plasma, Logistical reasons allowed inductively the geochemical solutions to be analyzed-Mass spectrometry (ICP-MS) type (Elmer Elam perken 6000) Technique, for the road side soils collected from Kirkuk city by (ICP-MS) for the reference soils. The concentrations of $\mathrm{As}, \mathrm{Cr}$ and $\mathrm{Cd}$ were determined in the solution of soil. Compound of replicates, reagent blanks and reference materials introduced by the ACME Analytical laboratories supported the excellent precision and accuracy of analytical results.

\section{Results and Discussion}

\subsection{Effect of pH}

The value of $\mathrm{pH}$ is equal minus logarithm of hydronium ion concentration, when this value is less than 7 means acidity, higher than 7 basicity and 7 means the solution is natural. The $\mathrm{pH}$ play an important role in the transition and movement of heavy metals in soil. The different physic-chemical and biological factors control the movement of metals in soil [13]. They suggested that a change in $\mathrm{pH}$ results in a conversion of element from one phase to another and thus statement the determination of mobility of heavy metals in soil. The results revealed that road side soil $\mathrm{pH}$ ranging in a narrow interval (7.1 - 7.8) Table 1, suggests that road side soil is mostly in neutral to sub alkaline condition which referred to the high rate of carbonate, ash and dust of anthropogenic origin [14]. The neutral to sub-alkaline condition of the road side soil may be concerning to the alkali composition in the atmosphere which can precipitate on the ground and influence the soil pH [15]. The soil PH to have showed higher effect on the solubility or metal detention in soil; the greater detention and lower solubility of metal happen at high soil $\mathrm{pH}[16]$. 
Table 1. Metal concentration in road side soil of right and left khasa in Kirkuk city in ppm.

\begin{tabular}{|c|c|c|c|c|c|c|c|c|c|c|c|}
\hline \multicolumn{6}{|c|}{ Right Khasa } & \multicolumn{6}{|c|}{ Left Khasa } \\
\hline $1 \mathrm{R}$ & Arbil & 11.21 & 0.56 & 180 & 7.80 & $1 \mathrm{~L}$ & Sulaimany & 9.10 & 0.32 & 126 & 7.21 \\
\hline $2 \mathrm{R}$ & Dibis & 7.40 & 0.41 & 172 & 7.98 & $2 \mathrm{~L}$ & Domez & 7.30 & 0.21 & 231 & 7.10 \\
\hline $3 R$ & Haweja & 8.32 & 0.32 & 190 & 7.10 & $3 \mathrm{~L}$ & Laylan & 8.10 & 0.4 & 242 & 7.32 \\
\hline $6 \mathrm{R}$ & Baghdad & 9.01 & 0.43 & 240 & 7.31 & $6 \mathrm{~L}$ & Banja Ail & 7.50 & 0.23 & 158 & 7.10 \\
\hline $7 \mathrm{R}$ & Wasty & 12.42 & 0.92 & 170 & 7.20 & $7 \mathrm{~L}$ & Musalla & 8.40 & 0.53 & 163 & 7.31 \\
\hline $8 \mathrm{R}$ & Arafa & 14.30 & 0.85 & 162 & 7.11 & $8 \mathrm{~L}$ & Iskan & 9.20 & 0.61 & 152 & 7.40 \\
\hline Min. & & 7.43 & 0.32 & 116 & 7.10 & Min. & & 7.30 & 0.21 & 112 & 7.10 \\
\hline Max. & & 14.30 & 0.92 & 273 & 7.80 & Max. & & 11.30 & 0.61 & 242 & 7.60 \\
\hline Av. & & 10.40 & 0.599 & 178.6 & 7.30 & Av. & & 8.290 & 0.4 & 165.8 & 7.20 \\
\hline
\end{tabular}

\subsection{Heavy Metals}

The levels of appearance of the metals specified that $\mathrm{Cr}$ has germinated as the prevailing metal, while $\mathrm{Cd}$ has the lowest concentration in roadside soil. It is observed form the soils right Khasa and left Khasa area that the average values of metals followed the sequence; $\mathrm{Cr}>\mathrm{As}>\mathrm{Cd}$ in both areas, while the mean value in right Khasa is higher concentricity of left Khasa. A comparison of metal average concentration in road side soil indicated that higher concentricity of $\mathrm{Cr}$, As, and Cd (178.1 - 165.8, $10.4-8.29$, 0.559 - $0.4 \mathrm{ppm}$ respectively) was observed in the right khasa Table 1 . This has considerable participation for the metal input from the construction works and other anthropogenic activities like oil refinery fuel station, vehicle agriculture, house hold dust, soil, dust, aerosols, burning of tire and burning of heavy duty oils which released particulates that are subsequently deposited on to the surface soil. This reflects a considerable effect of industrial of the environment of this area [17]. A brief discussion about single metals follows.

\subsubsection{Cadmium (Cd)}

The allowable limit of cadmium in soil, recommended by [18], is $3 \mathrm{ppm}$ Table 2. In the road side soil concentration of cadmium was recorded low the permissible limit. Concentricity of $\mathrm{Cd}$ in road side soil of right and left Khasa ranged between $0.32 \mathrm{ppm}$ to $0.92 \mathrm{ppm}$ with average 0.599 and $0.21 \mathrm{ppm}$ to $0.61 \mathrm{ppm}$ with average $0.4 \mathrm{ppm}$ respectively. Generally, $\mathrm{Cd}$ in the environment comes from different a ways of natural and manmade pollution.

The major natural resources of cadmium in the atmosphere are airborne soil particles, volcanogenic aerosols, forest fires and degassing of crustal rocks [19]. The manmade 
Table 2. Average concentration of As, $\mathrm{Cd}$ and $\mathrm{Cr}$ in studied area and compared with the permissible concentration of heavy metal in soil according to [18].

\begin{tabular}{cccc}
\hline Heavy metal & Right Khasa & Left Khasa & Permissible \\
\hline As & 10.4 & 8.29 & 10 \\
Cd & 0.599 & 0.4 & 3 \\
Cr & 178.6 & 165.8 & 100 \\
\hline
\end{tabular}

pollution resource of $\mathrm{Cd}$ components are combustion process of coal and oil, refuse incineration [20], pigments in plastic and consumed batteries. Road side receives different inputs of heavy metals from variety of mobile such as vehicular emission, oil combustion, waste incineration, construction and destruction activities in addition to resuspension of surrounding contaminated soil [10].

Cadmium in the road side soil in right Khasa of Kirkuk city was the highest; it ranges between $0.32-0.64 \mathrm{ppm}$ with an average of $0.599 \mathrm{ppm}$ Table 1 . The lowest value $\mathrm{Cd}$ was recorded in the left Khasa in Kirkuk city, it ranges between $0.21-0.62 \mathrm{ppm}$ with an average of $0.4 \mathrm{ppm}$. The high rate of $\mathrm{Cd}$ in right Khasa due to anthropogenic and industrial activities. The high concentricity of $\mathrm{Cd}$ in road soil in the right Khasa of studied area $0.599 \mathrm{ppm}$ could reflect the effect of human activity. As a result of urban industrial and agricultural practice, human activity can contribute to increased Cd levels [21], atmospheric deposition [22] and phosphate fertilizer use had resulted in the emission of significant amounts of $\mathrm{Cd}$ to the environment [23].

\subsubsection{Chromium (Cr)}

The permissible limit of chromium for soil is $100 \mathrm{ppm}$ recommended by [18] in road soil concentration of chromium was above the permissible limit Table 2. $\mathrm{Cr}$ is a low mobility element, especially under moderate oxidizing and reducing conditions and near-neutral $\mathrm{pH}$ vales. $\mathrm{Cr}^{6+}$ adsorption decreases with increasing $\mathrm{pH}$, and $\mathrm{Cr}^{3+}$ adsorption increases with increasing $\mathrm{pH}$. On the other hand, $\mathrm{Cr}$ is toxic for biotical systems [24]. Set of few large scale industrial activities such as dyes, ceramic and tanning are mentioned to contribute $\mathrm{Cr}$ [22]. Chromium in the road side soil in studied area was the highest, it ranges between $116-273 \mathrm{ppm}$ with an average178.6 ppm Table 1. The lowest value of $\mathrm{Cr}$ was recorded in the left Khasa, it was detected to vary from $112 \mathrm{ppm}$ to $242 \mathrm{ppm}$ with an average of $165.8 \mathrm{ppm}$.

The observed values were the average value from the world literature (84 ppm) [22], and also more than the reported world scale of unpolluted soil (83 ppm) [24].

However, $\mathrm{Cr}$ average value in the all study area road side soil samples to be 10 times higher that chromium content in the rural (control) soil (17.33 ppm) suggesting possible sources of $\mathrm{Cr}$ in the urban area.

\subsubsection{Arsenic (As)}

The permissible limit of Arsenic in soil is $10 \mathrm{ppm}$ recommended by [18] Table 2. In road side soil sample average concentricity of arsenic was 10.4 and $8.29 \mathrm{ppm}$ in both area respectively and it was concentration approximately equal the permissible limit 
Table 2.

The anthropogenic sources of arsenic include industrial emission, suspended arsenic rich soil, waste materials, coal burning and use of As-rich phosphate fertilizers [25]. The highest concentration of As was observed in the right Khasa (10.4 ppm) can indicate the areas with anthropogenic factor such as traffic and urbanization factors. Precipitation from atmospheric sources of arsenic can participate significantly to arsenic concentricity in soils. The ratio of atmospheric natural sources such as volcanic activity, to atmospheric anthropogenic sources like fossil fuel combustion, varies regionally but on average their mutual contributions are about equal [22]. Other non-atmospheric anthropogenic sources involve agricultural and industrial applications [26].

\subsection{Performance Evaluation of Soil Pollution}

There are many indices that used to estimate the rate of contamination by heavy metal. For this purpose and to subtend the aims of this project. To evaluate the pollution level of As, $\mathrm{Cd}$ and $\mathrm{Cr}$ in road side soil five indices were selected. These indices are Single Element Pollution Index (SEPT), Combined Pollution Index (CPI), Contamination Factor (CF), Pollution Load Index (PLI) and Geo-Accumulation Load Index (Igeo).

\subsubsection{Single Pollution Index}

An evaluated index is generally applied to measure environmental quality of soil and one simple and well known index is a single element pollution index (SEPI) which was used as assessment methods and to identify single-element contamination resulting in increased such heavy metal toxicity. The equation used to calculate (SEPI) is as follows:

$$
\text { SEPI = metal content in soil/permissible level of metal. }
$$

The acceptable levels for soil suggested by [24] and [18] adopted permissible rates and each weighty metal was classified as low contamination (SEPT $\leq 1$ ), moderation contamination $(1<\mathrm{SEPI} \leq 3)$ or high contamination SEPI $>3$ [18]. The SEPI value of As in road side soil of right and left Khasa varied from 0.7 to $1.43 \mathrm{ppm}$ and $0.62 \mathrm{ppm}$ to 1 . $13 \mathrm{ppm}$ respectively Table 3, which indicated low or moderate contamination level with an average of $1.04 \mathrm{ppm}$ to $0.82 \mathrm{ppm}$ respectively most road soil samples in right Khasa area were heavily polluted by As and classified as moderate contamination level. The SEPI value of Cr ranged from $1.2 \mathrm{ppm}$ to $2.73 \mathrm{ppm}$ and $1.18 \mathrm{ppm}$ to $2.42 \mathrm{ppm}$ respectively in both areas indicating moderate contamination with $\mathrm{Cr}$. The SEPI value for $\mathrm{Cd}$ varied from $0.11 \mathrm{ppm}$ to $0.28 \mathrm{ppm}$ and $0.1 \mathrm{ppm}$ to $0.2 \mathrm{ppm}$ respectively in both areas with an average $0.2 \mathrm{ppm}$ to $0.13 \mathrm{ppm}$ respectively suggesting low contamination with $\mathrm{Cd}$. The highest SEPI for $\mathrm{Cr}$ and As in the right Khasa area seems therefore to be that industrial soil, human activities, road dust and tire abrasion are polluted in the study area.

\subsubsection{Combined Pollution Index (CPI)}

Generally, extreme of the heavy metal pollution in the surface environment is associated with a mixture of contaminants rather than one metal contaminant [27], thus the idea of CPI which was used as another commonly assessment methods of multi-ele- 
Table 3. Single element pollution index values.

\begin{tabular}{|c|c|c|c|c|c|c|c|}
\hline \multicolumn{4}{|c|}{ Right Khasa } & \multicolumn{4}{|c|}{ Left Khasa } \\
\hline $\begin{array}{c}\text { Sample } \\
\text { No. }\end{array}$ & As & $\mathrm{Cd}$ & $\mathrm{Cr}$ & $\begin{array}{c}\text { Sample } \\
\text { No. }\end{array}$ & As & $\mathrm{Cd}$ & $\mathrm{Cr}$ \\
\hline $1 \mathrm{R}$ & 1.12 & 0.18 & 1.8 & $1 \mathrm{~L}$ & 0.91 & 0.10 & 1.26 \\
\hline $2 \mathrm{R}$ & 0.7 & 0.13 & 1.72 & $2 \mathrm{~L}$ & 0.73 & 0.07 & 2.31 \\
\hline $3 R$ & 0.85 & 0.11 & 1.90 & $3 \mathrm{~L}$ & 0.81 & 0.13 & 2.42 \\
\hline $4 \mathrm{R}$ & 0.95 & 0.21 & 2.73 & $4 \mathrm{~L}$ & 0.82 & 0.13 & 2.15 \\
\hline $5 \mathrm{R}$ & 0.86 & 0.15 & 1.64 & $5 \mathrm{~L}$ & 0.62 & 0.12 & 1.79 \\
\hline $6 \mathrm{R}$ & 0.92 & 0.14 & 2.40 & $6 \mathrm{~L}$ & 0.75 & 0.08 & 1.58 \\
\hline $7 \mathrm{R}$ & 1.24 & 0.31 & 1.70 & $7 \mathrm{~L}$ & 0.84 & 0.17 & 1.63 \\
\hline $8 \mathrm{R}$ & 1.43 & 0.28 & 1.62 & $8 \mathrm{~L}$ & 0.92 & 0.20 & 1.52 \\
\hline $9 \mathrm{R}$ & 1.12 & 0.22 & 1.20 & $9 \mathrm{~L}$ & 1.13 & 0.19 & 1.18 \\
\hline $10 \mathrm{R}$ & 1.05 & 0.24 & 1.16 & $10 \mathrm{~L}$ & 0.75 & 0.13 & 1.28 \\
\hline $11 \mathrm{R}$ & 1.19 & 0.21 & 1.78 & $11 \mathrm{~L}$ & 0.84 & 0.13 & 1.12 \\
\hline Min. & 0.7 & 0.11 & 1.16 & Min. & 0.62 & 0.07 & 1.12 \\
\hline Max. & 1.43 & 0.13 & 2.40 & Max. & 1.13 & 0.2 & 2.42 \\
\hline Av. & 1.04 & 0.19 & 1,78 & Av. & 0.82 & 0.13 & 1.65 \\
\hline
\end{tabular}

ment contamination resulting in increased over all metal toxicity [28]. The CPI is calculated by the average ratio of metal concentration in soil to assumed permissible level and was that classified as low $(\mathrm{CPI} \leq 1)$, middle $(1<\mathrm{CPI} \leq 2)$ or high $(\mathrm{CPI}>2)$ [18]. The tolerable levels for soil suggested by [18] and [24] were adopted as permissible levels and pollution index was calculated as:

$\mathrm{CPI}=($ metal content in soil/permissible level of metal $) /$ number of metals

Table 4 shows that the CPI is higher than 1 in most of road side soil samples in right Khasa (with exception of some samples). The range of contamination being more in the samples road side soil in right Khasa than the left road side soil samples in left Khasa area reflecting that road side soil in right Khasa was more polluted by the heavy metal in study area due to anthropogenic sources. Thus, it is very likely that many road side soil in right Khasa of Kirkuk city are moderately polluted with heavy metals. But the CPI of the As, Cd and Cr at left Khasa area was less than 1in most samples which indicates that average levels of metals are below the selected standards but does not necessarily indicate that there are no anthropogenic resources of enrichment over background level, and suggested single metals contamination [27]. The trend of CPI revealed that the right Khasa area greater than the left Khasa area. This trend indicated that the location along the right road side soil in Kirkuk city received more heavy metals input from anthropogenic induced sources.

\subsubsection{Index of Geo Accumulation Index (GAI)}

The index of (GIA) means assessment of contamination by contrasting the levels of 
Table 4. Combined pollution index values.

\begin{tabular}{cccccc}
\hline & Right Khasa & & \multicolumn{3}{c}{ Left Khasa } \\
\hline Sample No. & Road location & CPI & Sample No. & Road location & CPI \\
\hline $1 \mathrm{R}$ & Arbil & 1.03 & $1 \mathrm{~L}$ & Sulaimany & 0.76 \\
2R & Dibis & 0.85 & $2 \mathrm{~L}$ & Domez & 1.04 \\
3R & Haweja & 0.95 & $3 \mathrm{~L}$ & Laylan & 1.12 \\
$4 \mathrm{R}$ & Industrial & 1.30 & $4 \mathrm{~L}$ & Shorja & 1.03 \\
$5 \mathrm{R}$ & Kornish & 0.88 & $5 \mathrm{~L}$ & North car parking & 0.84 \\
6R & Baghdad & 1.15 & $6 \mathrm{~L}$ & Banja Ail & 0.80 \\
$7 \mathrm{R}$ & Wasty & 1.08 & $7 \mathrm{~L}$ & Musalla & 0.88 \\
8R & Arafa & 1.11 & $8 \mathrm{~L}$ & Iskan & 0.88 \\
9R & Teseen & 0.85 & $9 \mathrm{~L}$ & Nedaa & 0.83 \\
10R & Adar & 0.82 & $10 \mathrm{~L}$ & Qadsya & 0.72 \\
11R & University & 1.06 & 11L & Naser & 0.69 \\
Min. & & 0.82 & & & 0.69 \\
Max. & & 1.30 & & & 1.12 \\
Average & & 1.01 & & & 0.78 \\
\hline
\end{tabular}

heavy metal obtained to a background levels originally used with bottom precipitates (Muller, 1979). It was more used by numerous authors [29] has applied the index of Igeo, to assess of road soil pollution. Geo accumulation index as proposed by [30] and cited by [31] have been widely used to evaluate the degree of heavy metal contamination in wild and aquatic environment as expressed:

$$
\mathrm{GAI}=\operatorname{Ln}(\mathrm{Cm} / 1.5 \cdot \mathrm{Bm})
$$

where $\mathrm{Cm}$ is the mean concentration of metal $\mathrm{m}$ in soil and $\mathrm{Bm}$ is the background concentration of metal $\mathrm{m}$ (crustal abundant) [32], while 1.5 is a factor for possible difference in the background concentricity due to lithological differences. GAI is classified into descriptive seven classes as follows: class $0(\mathrm{GAI}<0)$ practically uncontaminated; class 1 (GAI 0 - 1) uncontaminated to moderately contaminated; class 2 (GAI 1 -2) moderately contaminated; class 3 (GAI 2 - 3) moderately to strongly contaminated; class 4 (GAI 3 - 4) strongly contaminated; clas 5 (GAI 4 - 5) strongly to extreme contaminated and class 6 (GAI $>5$ ) extremely contaminated [30].

The overall total (GAI) shows that the Cr in Kirkuk city (right and left Khasa) was found negative in most samples Table 5 and of class 0 , but it have positive value 0.04 , $0.39,0.27$ in samples 3, 4, 6 in right Khasa respectively and it have positive value $0.23,0$. 27, 0.16 in sample 2, 3, 4 in left Khasa respectively and belong the to the class 1 indicating un-polluted to moderately pollution. Arsenic (As) shows a positive index for all samples (except sample 2 in right Khasa and samples 2 and 5 in left Khasa were negative) indicating unpolluted to moderately polluted. Cd showed a positive geoaccumulation index in six samples of right Khasa are classified as class 2 moderately polluted and 5 sample (R4, R7, R8, R9, R10 and R11) in this area are classified as class 1, while in left 
Table 5. Result of Geo Accumulation Index (GAI) compared with the average crustal abundant (background value) in uncontaminated soil, adopted from [32].

\begin{tabular}{|c|c|c|c|c|c|c|c|}
\hline \multicolumn{4}{|c|}{ Right khasa } & \multicolumn{4}{|c|}{ Left khasa } \\
\hline Sample No. & As & $\mathrm{Cd}$ & $\mathrm{Cr}$ & Sample No. & As & $\mathrm{Cd}$ & $\mathrm{Cr}$ \\
\hline $1 \mathrm{R}$ & 0.39 & 0.91 & -0.01 & $1 \mathrm{~L}$ & 0.19 & 0.35 & -0.37 \\
\hline $2 \mathrm{R}$ & -0.01 & 0.60 & -0.06 & $2 \mathrm{~L}$ & -0.03 & -0.07 & 0.23 \\
\hline $3 R$ & 0.10 & 0.35 & 0.04 & $3 \mathrm{~L}$ & 0.08 & 0.57 & 0.27 \\
\hline $4 \mathrm{R}$ & 0.23 & 1.05 & 0.39 & $4 \mathrm{~L}$ & 0.09 & 0.57 & 0.16 \\
\hline $5 \mathrm{R}$ & 0.13 & 0.69 & -0.11 & $5 \mathrm{~L}$ & -0.19 & 0.49 & -0.02 \\
\hline $6 \mathrm{R}$ & 0.20 & 0.64 & 0.27 & $6 \mathrm{~L}$ & 0.00 & 0.02 & -0.14 \\
\hline $7 \mathrm{R}$ & 0.50 & 1.41 & -0.07 & $7 \mathrm{~L}$ & 0.11 & 0.86 & -0.11 \\
\hline $8 \mathrm{R}$ & 0.64 & 1.33 & -0.12 & $8 \mathrm{~L}$ & 0.20 & 0.99 & -0.18 \\
\hline $9 \mathrm{R}$ & 0.40 & 1.07 & -0.42 & $9 \mathrm{~L}$ & 0.41 & 0.96 & -0.43 \\
\hline $10 \mathrm{R}$ & 0.33 & 1.16 & -0.45 & $10 \mathrm{~L}$ & 0.00 & 0.55 & -0.35 \\
\hline $11 \mathrm{R}$ & 0.46 & 1.03 & -0.03 & $11 \mathrm{~L}$ & 0.11 & 0.57 & -0.49 \\
\hline Min. & -0.05 & 0.35 & -.45 & Min. & 0.00 & -0.07 & -0.43 \\
\hline Max. & 0.64 & 1,41 & 0.39 & Max. & 0.41 & 0.99 & 0.27 \\
\hline Av. & 0.32 & 0.98 & -0.02 & Av. & 0.10 & 0.57 & -0.09 \\
\hline $\begin{array}{l}\text { Background } \\
\text { value }\end{array}$ & 5 & 0.15 & 122 & $\begin{array}{c}\text { Background } \\
\text { value }\end{array}$ & 5 & 0.15 & 122 \\
\hline
\end{tabular}

Khasa the Cd shows a positive index for all sample (except sample 2L) indicating practically un polluted Table 3 .

\subsubsection{Contamination Factor (CF)}

The grade of contamination by metals was determined by applying the contamination factor $(\mathrm{CF})$ that can be calculated as:

$$
\mathrm{CF}=\mathrm{Cm} \text { sample/Bm background }
$$

where $\mathrm{Cm}$ and $\mathrm{Bm}$ are defined above where the contamination factor $\mathrm{CF}<1$ indicates low contamination; $1 \leq \mathrm{C} \mathrm{F}<3$ refers to moderate contamination, $3 \leq \mathrm{CF}<6$ means considerable contamination and $\mathrm{CF}>6$ indicates very high contamination factor. The contamination factor for As, $\mathrm{Cr}$ and $\mathrm{Cd}$ was calculated in the study areas and the results which have indicated in Table 6.

Cadmium in Kirkuk city especially in right Khasa classified as class 3 in most samples and representing a considerable contamination except samples no. $2 \mathrm{R}, 3 \mathrm{R}$ and $6 \mathrm{R}$ represents a moderate contamination (class 2) (Table 6). Samples collected from left Khasa displayed contamination factor value not exceed 3 indicating a contamination rate of low to moderate contamination except sample no $4 \mathrm{~L}, 7 \mathrm{~L}, 8 \mathrm{~L}, 9 \mathrm{~L}, 10 \mathrm{~L}$ and $11 \mathrm{~L}$ represents a moderate contamination. The resource of contaminated materials might be attributed to the automobile emission, industrial activity and agriculture which used phosphate fertilizers, these activities which abundant in right Khasa rather than the left Khasa had been received of significant amounts of $\mathrm{Cd}$ to the environment of the area of 
Table 6. Results of As, Cd, Cr and their Contamination Factor (CF) and Pollution Load Index (PLI) compared with the average crustal abundance (background value) in un contaminated soil adopted from [32].

\begin{tabular}{|c|c|c|c|c|c|c|c|c|c|}
\hline \multicolumn{5}{|c|}{ Right Khasa } & \multicolumn{5}{|c|}{ Left Khasa } \\
\hline \multirow{2}{*}{ Sample No. } & \multicolumn{3}{|c|}{ CF } & \multirow{2}{*}{ PLI } & \multirow{2}{*}{ Sample No. } & \multicolumn{3}{|c|}{ CF } & \multirow{2}{*}{ PLI } \\
\hline & As & Cd & $\mathrm{Cr}$ & & & As & $\mathrm{Cd}$ & $\mathrm{Cr}$ & \\
\hline $1 \mathrm{R}$ & 2.24 & 3.73 & 1.47 & 2.30 & $1 \mathrm{~L}$ & 1.82 & 2.13 & 1.03 & 1.58 \\
\hline $2 \mathrm{R}$ & 1.48 & 2.73 & 1.40 & 1.78 & $2 \mathrm{~L}$ & 1.46 & 1.4 & 1.89 & 1.56 \\
\hline $3 \mathrm{R}$ & 1.66 & 2.13 & 1.55 & 1.76 & $3 \mathrm{~L}$ & 1.62 & 2.66 & 1.98 & 2.04 \\
\hline $4 \mathrm{R}$ & 1.9 & 4.26 & 2.33 & 2.65 & $4 \mathrm{~L}$ & 1.64 & 2.66 & 1.76 & 1.97 \\
\hline $5 \mathrm{R}$ & 1.72 & 3.0 & 1.34 & 1.90 & $5 \mathrm{~L}$ & 1.24 & 2.46 & 1.46 & 1.64 \\
\hline $6 \mathrm{R}$ & 1.84 & 2.86 & 1.96 & 2.17 & $6 \mathrm{~L}$ & 1.5 & 1.53 & 1.29 & 1.43 \\
\hline $7 \mathrm{R}$ & 2.48 & 5.13 & 1.39 & 2.76 & $7 \mathrm{~L}$ & 1.68 & 3.53 & 1.33 & 1.99 \\
\hline $8 \mathrm{R}$ & 2.86 & 5.66 & 1.32 & 2.77 & $8 \mathrm{~L}$ & 1.84 & 4.06 & 1.24 & 2.1 \\
\hline $9 \mathrm{R}$ & 2.24 & 4.4 & 0.98 & 2.12 & $9 \mathrm{~L}$ & 2.26 & 3.9 & 0.96 & 2.03 \\
\hline $10 \mathrm{R}$ & 2.1 & 4.8 & 0.95 & 2.12 & $10 \mathrm{~L}$ & 1.5 & 2.6 & 1.04 & 1.59 \\
\hline $11 \mathrm{R}$ & 2.38 & 4.2 & 1.46 & 2.44 & $11 \mathrm{~L}$ & 1.68 & 2.66 & 0.91 & 1.60 \\
\hline Min. & 1.48 & 2.73 & 0.95 & 1.76 & Min. & 1.46 & 1.4 & 0.91 & 1.43 \\
\hline Max. & 2.86 & 5.13 & 2.33 & 2.76 & Max. & 2.26 & 4.06 & 1.98 & 2.1 \\
\hline Av. & 2.08 & 3.99 & 1.46 & 2.29 & Av. & 1.65 & 2.66 & 1.36 & 1.81 \\
\hline $\begin{array}{c}\text { Background } \\
\text { value }\end{array}$ & 1.0 & 1.0 & 1.0 & & $\begin{array}{c}\text { Background } \\
\text { value }\end{array}$ & 1.0 & 1.0 & 1.0 & \\
\hline
\end{tabular}

study especially in the right Khasa. The heavy metals have been added in to urban soil through urban wastes [33] and most importantly through vehicle emission [34]. Contamination factor for As and $\mathrm{Cr}$ in the studied area are classified as class 2 and represent moderate contamination in all samples (Table 6). As, for examples is known to come from the utilize of industrial emission, coal burning and phosphate fertilizers [25], whereas Cd from tire abrasion, industrial and incinerator emission [35]. The source of $\mathrm{Cr}$ in road soil is known to come from the use of paints manufacture, leather tanning industries, metal plating, ceramic manufacture are reported to contribute $\mathrm{Cr}$ in the environment [22].

\subsubsection{Pollution Load Index (PLI)}

Pollution Load Index (PLI) has been suggested by [36] for evaluating particular site. This index expressed as:

$$
\mathrm{PLI}=(\mathrm{CF} 1 \times \mathrm{CF} 2 \times \mathrm{CF} 3 \times \cdots \times \mathrm{CFn}) / \mathrm{n}
$$

where $\mathrm{n}$ is the number of metals. The PLI provides sample but comparative means for assessing a site quality, where a value of PLI $<1$ denote perfection; PLI $=1$ present that only base line levels of pollutant are present and PLI $>1$ could indicate deterioration if site quality [36]. Pollution load index are showed in (Table 6). PLI in the right Khasa ranges from $1.76 \mathrm{ppm}$ to $2.77 \mathrm{ppm}$ with an average $2.29 \mathrm{ppm}$, while in the left Khasa 
ranges from $1.43 \mathrm{ppm}$ to $2.1 \mathrm{ppm}$ with an average $1.81 \mathrm{ppm}$. All samples in studied areas have PLI more than 1 indicates a deterioration of site quality. All samples in Kirkuk city (Right and left Khasa) are more that base line level (1.0).

\section{Conclusion}

The results of the present study revealed significant presence of $\mathrm{As}, \mathrm{Cr}$, and $\mathrm{Cd}$ in the road side soil in Kirkuk city. The results appeared the following trend in road side soil: $\mathrm{Cr}>\mathrm{As}>\mathrm{Cd}$, but the average concentrations of this metal in Khasa area of Kirkuk city showed abundant in right area more than the left area. The main concentration of As $10.4 \mathrm{ppm}$ and $8.29 \mathrm{ppm}$ respectively, $\mathrm{Cr}$ was $178.9 \mathrm{ppm}$ and $165.8 \mathrm{ppm}$, while Cd was $0.59 \mathrm{ppm}$ and $0.4 \mathrm{ppm}$ respectively. It is clear that the pollutant affected the right Khasa more that the left Khasa road side because of the predominant industrial activities such as (oil and gas company) and in an increasing the pollutants. The result of SEPI values indicated moderate contamination with As and $\mathrm{Cr}$, while SEPI values of Cd suggesting low contamination with this element in right Khasa. The CPI values indicated moderate contamination with As, $\mathrm{Cr}$ and $\mathrm{Cd}$ in most of the samples in right Khasa and this specified that the right area received more heavy metals input from anthropogencally stimulated sources. The contamination factor in study area was moderately to considerable contamination with $\mathrm{Cd}$ in most samples especially in the right Khasa, slightly contamination with As and presently moderate contaminated with Crin both studied area. The result of Igeo in the most samples in right Khasa showed unpolluted to moderately polluted with cadmium.

\section{Recommendations}

It was recommended from the present study that:

1) Increasing green areas and implantation more trees because trees help in cleaning soil, protecting its fertility and in reducing the level of pollutants.

2) Continuous monitoring of concentrations of heavy metals, especially Cd and As to avoid being beat permissible limit.

3) The severe laws should be activated to prevent hazardous pollutants to the environment and increase environmental knowing among the people.

\section{Acknowledgements}

The author wish to thank Mr. Marwan Al-Jobory and Qayssar M. Ajaj, the maps designer of the search and, Mr. Ali Al-Saleh, the linguist. Thanks must also go to the ACME laboratory in Canada for helping me with the analyses of heavy metals.

\section{References}

[1] Abah, J., Mashebe, P. and Onjefu, S.A. (2014) Survey of the Levels of Some Heavy Metals in Roadside Dusts along Katima Mulilo Urban Road Construction, Namibia American. Journal of Environmental Protection, 3, 19-27.

[2] Ubwa, S.T., Abah, J., Ada, C.A. and Alechenu, E. (2013) Levels of Some Heavy Metals Con- 
tamination of Street Dust in the Industrial and High Traffic Density Areas of Jos Metropolis. Journal of Biodiversity and Environmental Sciences, 3, 13-21.

[3] Li, X., Poon, C.-S. and Liu, P.S. (2001) Heavy Metal Contamination of Urban Soils and Street Dusts in Hong Kong. Applied Geochemistry, 16, 1361-1368.

http://dx.doi.org/10.1016/S0883-2927(01)00045-2

[4] Charron, A., Harrison, R.M. and Quincey, P. (2007) What Are the Sources and Conditions Responsible for Accidences of the $24 \mathrm{~h} \mathrm{PM} \mathrm{Limit} \mathrm{Value}\left(5010 \mu \mathrm{g} / \mathrm{m}^{3}\right)$ at a Heavily Trafficked London Site? Atmospheric Environment, 41, 1960-1975. http://dx.doi.org/10.1016/j.atmosenv.2006.10.041

[5] Li, X. and Huang, C. (2007) Environment Impact of Heavy Metals on Urban Soil in the Vicinity of Industrial Area of Baoji City P.R. China. Environmental Geology, 52, 1631-1637. http://dx.doi.org/10.1007/s00254-006-0608-3

[6] Paterson, E., Sanka, M. and Clark, L. (1996) Urban Soils as Pol-Lutant Sinks: A Case Study from Aberdeen, Scotland. Applied Geochemistry, 11, 129-131. http://dx.doi.org/10.1016/0883-2927(95)00081-X

[7] Wang, X.S., Qin, Y. and Sun, S.X. (2005) Accumulation and Sources of Heavy Metals in Urban Topsoil: A Case Study from the City of Xuzhou, China. Environmental Geology, 48, 101-107. http://dx.doi.org/10.1007/s00254-005-1270-x

[8] Davydova, S. (2005) Heavy Metals as Toxicants in Big Cities. Microchemical Journal, 79, 133-136. http://dx.doi.org/10.1016/j.microc.2004.06.010

[9] Meza-Figueroa, D, De La O-Villanueva, M. and De La Parra, M.L. (2006) Heavy Metal Distribution in Dust from Elementary Schools in Hermosillo, Sonora, Mexico. Atmospheric Environment, 41, 276-288. http://dx.doi.org/10.1016/j.atmosenv.2006.08.034

[10] Al-Khashman, O.A. (2004) Heavy Metal Distribution in Dust, Street Dust and Soils from the Work Place in Karak Industrial Estate, Jordan. Atmospheric Environment, 38, 68036812. http://dx.doi.org/10.1016/j.atmosenv.2004.09.011

[11] Arslan, H. (2001) Heavy Metals in Street dust in Bursa, Turkey. Journal of Trace and Microprobe Techniques, 19, 439-445. http://dx.doi.org/10.1081/TMA-100105058

[12] Ferreira-Baptista, L. and De Miguel, E. (2005) Geochemistry and Risk Assessment of Street Dust in Luanda, Angola: A Tropical Urban Environment. Atmospheric Environment, 39, 4501-4512. http://dx.doi.org/10.1016/j.atmosenv.2005.03.026

[13] Naim, S., Ozcan, H.K., Demir, G., Nemlioglu, S. and Bayat, C. (2003) Determination of Heavy Metal Concentrations in Street Dusts in Istanbul E-5 High Way. Environmental International, 29, 979-985.

[14] Lu, S.G. and Bai, S.Q. (2010) Contamination and Potential Mobility Assessment of Heavy Metals in Urban Soil of Hougzhou, China. Relationship with Different Land Uses. Environmental Earth Sciences, 60, 1481-1490. http://dx.doi.org/10.1007/s12665-009-0283-2

[15] Kim, K.W., Myung, J.K., Ahn, J.S. and Chon, H.T. (1998) Heavy Metal Contamination in Dust and Stream Sediment in the Taejon Area, Korea. Journal of Geochemical Exploration, 64, 409-419. http://dx.doi.org/10.1016/S0375-6742(98)00045-4

[16] Skrbic, B. and Miljevic, N. (2002) An Evaluation of Residues at an Oil Refinery Site Following Fires. Journal of Environmental Science and Health, 37, 1029-1039. http://dx.doi.org/10.1081/ESE-120004520

[17] Thornton, I. (1991) Metal Contamination of Soils in Urban Areas. In: Bullock, P. and Gregory, P.J., Eds., Soils in the Urban Environment, Blackwell, Oxford, 47-75. http://dx.doi.org/10.1002/9781444310603.ch4

[18] Chen, T., Zheng, B., Lei, Y.M., Huang, Z.C., Wu, H.T., Chen, H., Fan, K.K., Yu, K., Wu, X. 
and Tian, Q.Z. (2005) Assessment of Heavy Metal Pollution in Surface Soils of Urban Parks in Beijing, China. Chemosphere, 60, 542-551.

http://dx.doi.org/10.1016/j.chemosphere.2004.12.072

[19] Bennett, C.A. and Franklin, N.L. (1963) Statistical Analysis in Chemistry and the Chemical Industry. John Wiley and Sons, New York, Section 3, 44.

[20] Laskus, L., Bake, D., König, R., van der Meulen, A. and van Elzakker, B.G. (1989) Measurement of Particle Size Distribution and Dust Concentration. Staub, Reinhaltung der Luft, 49, 395-400.

[21] Adriano, D.C (2001) Trace Elements in Terrestrial Environments: Biogeochemistry, Bioavailability and Risks of Metals. 2nd Edition, Springer, New York, 867.

http://dx.doi.org/10.1007/978-0-387-21510-5

[22] Alloway, B.J. (1995) Heavy Metals in Soils. Blackie Academic and Professional, London.

[23] Kisku, G.C., Barman S.C. and Bhrgava, S.K. (2000) Contamination of Soils and Plants with Potentially Toxic Elements Irrigated with Mixed Industrial Effluent and Its Impact on the Environment. Water, Air \& Soil Pollution, 120, 121-137. http://dx.doi.org/10.1023/A:1005202304584

[24] Kabata-Pendias, A. and Pendias, H. (2001) Trace Element in Soils and Plants. CRC Press, London.

[25] Kabata-Pendias, A. and Piotrowska, M. (1999) Impact of $\mathrm{Zn}$ and Pb Smelter Flue-Dust on $\mathrm{Cd}, \mathrm{Zn}$ and $\mathrm{Pb}$ Speciation in Soil and Their Availability to Spring Barley. Bulletin de P Academie Serbe des Sciences et des Arts, 119, 77-82.

[26] Smith, A.H., Goycolea, M., Haque, R. and Biggs, M.L. (1998) Marked Increase in Bladder and Lung Cancer Mortality in a Region of Northern Chile Due to Arsenic in Drinking Water. American Journal of Epidemiology, 147, 660-669. http://dx.doi.org/10.1093/oxfordjournals.aje.a009507

[27] Jung, M.C. (2001) Heavy Metal Contamination of Soils and Waters in and Around the Imcheon Au-Ag Mine, Korea. Applied Geochemistry, 16, 1369-1375.

http://dx.doi.org/10.1016/S0883-2927(01)00040-3

[28] Li, X., Lee, S., Wong, S., Shi, W. and Thornton, I. (2004) The Study of Metal Contamination in Urban Soils of Hong Kong Using a GIS-Based Approach. Environmental Pollution, 129, 113-124. http://dx.doi.org/10.1016/j.envpol.2003.09.030

[29] Gowd, S.S., Reddy, M.R. and Govil, P.K. (2010) Assessment of Heavy Metal Contamination in Soils at Jajmau (Kanpur) and Unnao Industrial Areas of the Ganga Plain, Uttar Pradesh, India. Journal of Hazardous Materials, 174, 113-121. http://dx.doi.org/10.1016/j.jhazmat.2009.09.024

[30] Muller, G. (1969) Index of Geoaccumulation in Sediments of the Rhine River. Journal of Geology, 2, 108-118.

[31] Lokeshwari, H. and Chandrappa, G.T. (2006) Heavy Metals Content in Water, Water Hyacinth and Sediments of Laibagh Tank, Bangalore (India). Journal of Environmental Engineering and Science, 48, 183-188.

[32] Dineley, D., Hawkes, D., Hancock, P. and Williams, B. (1976) Earth Resources-A Dictionary of Terms and Concepts. Arrow Books Ltd., London, 205.

[33] Wei, C., Wang, C. and Yang, L. (2009) Characterizing Spatial Distribution and Sources of Heavy Metals in the Soils from Miningsmelting Activities in Shuikoushan, Hunan Province, China. Journal of Environmental Sciences, 21, 1230-1236. http://dx.doi.org/10.1016/S1001-0742(08)62409-2

[34] Xia, X., Chen, X., Liu, R. and Liu, H. (2011) Heavy Metals in Urban Soils with Various 
Types of Land Use in Beijing, China. Journal of Hazardous Materials, 186, 2043-2050. http://dx.doi.org/10.1016/j.jhazmat.2010.12.104

[35] Thorpe, A. and Harrison, R.M. (2008) Sources and Properties of Non-Exhaust Particulate Matter from Road Traffic: A Review. Science of the Total Environment, 400, 270-282. http://dx.doi.org/10.1016/j.scitotenv.2008.06.007

[36] Thomilson, D.C., Wilson, D.J., Harris, C.R. and Jeffrey, D.W. (1980) Problem in Heavy Metals in Estuaries and the Formation of Pollution Index. Helgoländer Meeresuntersuchungen, 33, 566-575. http://dx.doi.org/10.1007/BF02414780

Submit or recommend next manuscript to SCIRP and we will provide best service for you:

Accepting pre-submission inquiries through Email, Facebook, LinkedIn, Twitter, etc. A wide selection of journals (inclusive of 9 subjects, more than 200 journals)

Providing 24-hour high-quality service

User-friendly online submission system

Fair and swift peer-review system

Efficient typesetting and proofreading procedure

Display of the result of downloads and visits, as well as the number of cited articles Maximum dissemination of your research work

Submit your manuscript at: http://papersubmission.scirp.org/

Or contact gep@scirp.org 